\title{
Genetic determinants of amidating enzyme activity and its relationship with metal cofactors in human serum
}

\author{
Eric D Gaier ${ }^{1}$, Alison Kleppinger ${ }^{2}$, Martina Ralle”, Jonathan Covault ${ }^{1,4}$, Richard E Mains ${ }^{1}$, Anne M Kenny ${ }^{2}$ \\ and Betty A Eipper ${ }^{{ }^{*}}$
}

\begin{abstract}
Background: $a$-amidation is a final, essential step in the biosynthesis of about half of all peptide hormones and neurotransmitters. Peptidylglycine a-amidating monooxygenase (PAM), with enzymatic domains that utilize $\mathrm{Cu}$ and $\mathrm{Zn}$, is the only enzyme that catalyzes this reaction. PAM activity is detected in serum, but its significance and utility as a clinical biomarker remain unexplored.

Methods: We used well-established enzymatic assays specific for the peptidylglycine-a -hydroxylating monooxygenase (PHM) and peptidyl-a-hydroxyglycine a-amidating lyase (PAL) domains of PAM to quantify amidating activity in the sera of 144 elderly men. Relationships between PHM and PAL activity and serum levels of their respective active-site metals, Cu and Zn, were analyzed. Study participants were also genotyped for eight non-coding single nucleotide polymorphisms (SNPS) in PAM, and relationships between genotype and serum enzyme activity and metal levels were analyzed.

Results: Serum PHM and PAL activities were normally distributed and correlated linearly with each other. Serum PAL activity, but not serum PHM activity, correlated with serum Cu; neither activity correlated with serum Zn. Study subjects possessing the minor alleles for rs32680 had lower PHM and PAL activities, and subjects with minor alleles for rs11952361 and rs10515341 had lower PHM activities.

Conclusions: Our results characterize large variation in serum amidating activity and provide unique insight into its potential origin and determinants. Common non-coding polymorphisms affect serum amidating activity and $\mathrm{Cu}$ levels. Serum amidating activity should be explored as a biomarker for functionality in the elderly and in additional study groups.
\end{abstract}

Keywords: PAM, Neuropeptide, Copper, SNP

\section{Background}

Peptides are ancient signaling molecules, with roles in plants and animals. Despite their diversity, many secreted peptides share a common biosynthetic pathway. Carboxy-terminal $\alpha$-amidation is a final and essential step in the synthesis of about half of bioactive peptides in humans [1,2]. While the list of biologically active peptide products continues to grow, our understanding

\footnotetext{
* Correspondence: eipper@uchc.edu

${ }^{1}$ Department of Neuroscience, University of Connecticut Health Center, 06030 Farmington, CT, USA

Full list of author information is available at the end of the article
}

of the complex network of peptidergic signaling pathways and their clinical relevance remains modest.

Peptidylglycine $\alpha$-amidating monooxygenase (PAM), an integral membrane protein, is the only enzyme known to catalyze the $\alpha$-amidation reaction [3,4]. The first part of this two-step reaction, the $\alpha$-hydroxylation of peptidylglycine, is accomplished by the peptidylglycine $\alpha$-hydroxylating monooxygenase (PHM: EC1.14.17.3) domain of PAM, which requires $\mathrm{Cu}[5,6]$. The second step, $\mathrm{C}-\mathrm{N}$ bond cleavage to yield the final amidated product plus glyoxylate, is accomplished by peptidyl- $\alpha$-hydroxyglycine $\alpha$-amidating lyase (PAL:4.3.2.5), which uses Zn, although several other divalent metals can substitute for $\mathrm{Zn}$. Tissue-specific 
endoproteolytic cleavage of PAM can produce soluble PHM and PAL, which can be secreted and remain active outside the cell $[7,8]$. PHM and PAL activity is present in mammalian serum, although the tissue source remains unknown.

The human PAM gene contains 25 exons extending over $160 \mathrm{~kb}$ at chromosome 5q21.1. Alternative splicing generates at least 5 isoforms [9]. The gene interval shows a low level of recombination and is contained in a single large haplotype block. Little is known about the regulation of $P A M$ expression in humans or about potential functional genetic variations in the $P A M$ gene. There are nearly 100 annotated coding variants in the human PAM gene and their functional consequences have yet to be tested (http://www.ncbi.nlm.nih.gov/SNP/ snp_ref.cgi?locusId=5066).

Animal models suggest that one mechanism of regulating PAM expression involves changes in its mRNA stability. In rat models, estrogen down-regulates PAM mRNA in the anterior pituitary via a change in nuclear stability [10]. This effect may be related to changes in the La protein, which binds to a nuclear retention domain in the $3^{\prime}$-untranslated region of PAM mRNA [11]. With regard to this potential regulation by the La protein, we note that the 3'UTR of human PAM contains a SNP, rs5855 (A/G, G is the minor, but ancestral, allele), positioned $60 \mathrm{bp}$ upstream of the La protein nuclear retention binding site. The A-allele generates a polyadenylation consensus sequence (AAUAAA), which is predicted to generate PAM mRNA variants lacking the La protein nuclear retention signal.

Genetic ablation of the gene encoding Pam results in embryonic lethality in mice and complete absence of amidating activity [4]. Pam heterozygosity $\left(\mathrm{Pam}^{+/-}\right)$results in temperature dysregulation, impairments in vasoconstriction, increased susceptibility to seizures, an anxiety-like phenotype, learning and memory deficits and neuronal hyperexcitability in limbic brain structures [12-14]. Interestingly, many of these deficits can be recapitulated in normal mice by mild dietary $\mathrm{Cu}$ restriction and are reversed in $\mathrm{Pam}^{+/-}$mice by dietary $\mathrm{Cu}$ supplementation. These observations suggest the presence of a complex, bi-directional relationship between $\mathrm{Cu}$ availability and Pam expression in mice $[15,16]$ (for review see [17]).

Serum PHM and PAL activity have not been studied in a large human cohort. In this study, we investigate the relationship between serum PHM and PAL activities and serum metal levels in a previously characterized population of elderly men with frailty characteristics $[18,19]$. We genotyped these men for single nucleotide polymorphisms (SNPs) in non-coding regions of the PAM gene and analyzed the relationship of $P A M$ genotype with enzyme activities and $\mathrm{Cu}$ levels.

\section{Methods}

\section{Study population}

Frail men aged 60 years or older, residing in the community or assisted living, were recruited to participate in the study. The individuals were screened for potential participation in a previously reported study to assess testosterone effects on bone and frailty in men [18] and the relationship between serum $\mathrm{Cu}$ and the $\mathrm{Cu} / \mathrm{Zn}$ ratio with measures of independence and frailty [19]. The data used in this analysis are baseline assessments. All study participants provided written informed consent. Analysis was limited to men due to the hypothesis and design of the original study on testosterone; a similar female cohort was not available for study. The Institutional Review Board at the University of Connecticut Health Center approved the study.

Our sample was of moderate size for the detection of genotype/phenotype correlations. A sample of 120 men with markers having minor allele frequencies of 0.16-0.44 has $80 \%$ power to detect large effects $(d>0.7)$ for the minor allele in recessive genetic models and $80 \%$ power to detect medium effects $(\mathrm{d}=0.5)$ using dominant minor allele genetic models. The effect sizes relative to PHM enzyme activity observed for markers rs32680, rs11952361 and rs10515341 under the recessive model were 0.94, 0.57 and 0.84 . For marker rs10038600, the observed effect size was 0.38 for the dominant minor allele model. Analysis of larger samples will be important to verify the genotype-phenotype associations observed.

\section{Biochemical analysis}

PHM activity was assayed as described using a trace amount of $\left[{ }^{125} \mathrm{I}\right]$-Ac-Tyr-Val-Gly, $0.5 \mu \mathrm{M}$ Ac-Tyr-Val-Gly and $4.0 \mu \mathrm{M} \mathrm{CuSO}_{4}$; serum samples were diluted 10 -fold into $20 \mathrm{mM} \mathrm{Na}$ TES, pH 7.4, $10 \mathrm{mM}$ mannitol, $1 \mathrm{mg} / \mathrm{ml}$ bovine serum albumin, 1\% TX-100 (Surfact-Amps X-100) (Thermo Scientific) and $4 \mu \mathrm{l}$ of the dilution $(0.4 \mu \mathrm{l}$ of serum) was assayed in triplicate in $100 \mathrm{mM}$ Na MES, pH 5.5 [13]. In the absence of exogenous $\mathrm{Cu}$, PHM activity cannot be detected in human serum; based on dose-response curves (data not shown), the addition of exogenous $\mathrm{Cu}$ $\left.(4.0 \mu \mathrm{M} \mathrm{CuSO})_{4}\right)$ yielded maximal levels of PHM activity for serum samples in both the upper and lower quintiles. PAL activity was assayed in triplicate from the same dilutions $(0.2 \mu \mathrm{l}$ of serum) using a trace amount of $\left[{ }^{125} \mathrm{I}\right]$-Ac-Tyr-Val- $\alpha$-hydroxyglycine, $0.5 \mu \mathrm{M}$ Ac-Tyr-

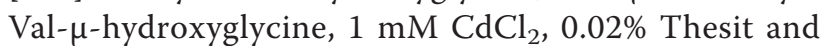
$100 \mathrm{mM}$ Na MES, pH 5.5 [20]. Ceruloplasmin was assayed in duplicate using $o$-dianisidine dihydrochloride [21,22]; a linear response was observed with 1.0 to $5.0 \mu \mathrm{l}$ serum and samples were compared using $2.5 \mu \mathrm{l}$ serum.

As reported previously [19], inductively coupled plasma mass spectrometry analysis of $\mathrm{Cu}$ and $\mathrm{Zn}$ were performed using an Agilent 7700x equipped with an ASX 500 autosampler at a radio frequency power of $1550 \mathrm{~W}$, argon 
plasma gas flow rate of $15 \mathrm{~L} / \mathrm{min}$, and argon carrier gas flow rate of $1.04 \mathrm{~L} / \mathrm{min}$. $\mathrm{Cu}$ and $\mathrm{Zn}$ were measured in kinetic energy discrimination mode using $\mathrm{He}$ gas $(4.3 \mathrm{~mL} / \mathrm{min})$. For analysis, serum samples were diluted 25 -fold into $1 \% \mathrm{HNO}_{3}$ (Fisher Scientific). Data were quantified using a 5-point [0-1000 ppb (ng/g)] calibration curve with external standards. For each sample, data were acquired in triplicate and averaged. An internal standard (Er) introduced with the sample was used to monitor for plasma instabilities and correct for changes in sample matrix.

\section{Genotyping}

Selection of markers: There are no validated common (>5\%) coding variants in the PAM gene. The potentially functional rs5855 SNP upstream of the PAM mRNA La protein nuclear retention binding site was identified using in silico inspection of 3'UTR SNPs. Amplification of the 3'-region of PAM mRNA via cDNA copies from human fibroblasts indicated that the A-allele yielded truncated isoforms of PAM mRNA (Jensen and Covault, unpublished). The 3'UTR rs5855 SNP together with 7 TagSNPs identified using the 2008 HapMap CEU population dataset were genotyped using closed-tube fluorescent TaqMan 5'nuclease allelic discrimination assays. DNA was extracted from peripheral blood samples using a commercial kit (Gentra Puregene, Qiagen, Valencia, CA). Commercial TaqMan assays were used for six markers: rs32680, rs10038600, rs7733485, rs11952361, rs10515341, and rs17296280 [Applied Biosystems Inc. (ABI) Foster City, CA]. Primers and MGB probes were designed using Primer Express v3.0 software (ABI) for 2 SNPs rs249496 (primers: TGGCGCTGGGGCTAGAC and ATGATG ACTGACGCGGGTTT; MBG probes: 6-fam-TGCCT TATGACTCCGGA and vic-TGCCTTATCACTCCGGA) and rs5855 (primers: TGCCTTTCCTGTTCAGCATTC and TGTCGTCATGTAGCACAAAGTTTCT; MBG probes: 6-fam-CCTGTGGCAGTAAA and vic-CTGT GGCAATAAA). Fluorescence plate reads and genotype calls were made using a 7500 Sequence Detection System following PCR amplification for 40 cycles at $95^{\circ} \mathrm{C}$ for 15 seconds followed by $60^{\circ} \mathrm{C}$ for 60 seconds. Linkage disequilibrium for the eight SNP markers in this sample of 140 Caucasian men was examined using the software program Haploview v3.2.2 [23].

\section{Statistical analysis}

All variables were checked for normal distribution and the impact of outliers. Normality was tested using simple sample Chi Squared or Kolmogorov-Smirnov tests. Correlation coefficients were used to detect preliminary associations of PHM and PAL activities with serum metals with other measures of interest. Dominant and recessive effects of the minor allele for each SNP were examined using independent groups t-tests comparing either major allele homozygotes with minor allele carriers with major allele homozygotes (dominant minor allele effect model) or minor allele homozygotes vs. major allele carriers (recessive minor allele effect model). Levene's test was used to guide equal variance assumptions in each comparison. Statistical analyses were performed using SPSS version 22.0.

\section{Results}

\section{Subject population}

One hundred and forty-four community dwelling elderly men were included in this analysis. Baseline information for this sample has been reported previously [19]; their mean age was $77.1 \pm 7.6$ years and their mean BMI was $26.9 \pm 4.4 \mathrm{~kg} / \mathrm{m}^{2}$. Most men (91\%) met the criteria for frailty $(18 \%)$ or prefrailty $(72 \%)$. Approximately $50 \%$ met criteria for sarcopenia or low muscle mass commonly associated with aging [24]. A complete set of enzyme activity, serum metal measures and genotype information were available for 120 subjects.

\section{Serum amidating activity}

Assays were performed after adding exogenous metals and reflect the amount of PHM and PAL protein, not metallation of each enzyme, in serum [13]. Average serum enzyme activity was $5.51 \pm 1.11 \mathrm{nmol} / \mathrm{mL} / \mathrm{h}$ for PHM and $19.1 \pm 4.5 \mathrm{nmol} / \mathrm{mL} / \mathrm{h}$ for PAL (Table 1). Serum PHM and PAL activities, and the PHM/PAL ratio were normally distributed (Figure 1A,B,C). PHM and PAL activities were significantly correlated $(p<0.05)$ (Figure 1D), as would be expected for enzymes cleaved from the same bifunctional precursor. The average ratio of PHM to PAL activity in serum was $0.30 \pm 0.01$ (Table 1). Assayed under similar conditions, with the peptide substrate concentration well below $K_{M}$, purified bifunctional PAM-3 yielded a PHM/PAL activity ratio of 0.2 when intact and 0.6 to 0.8 after proteolytic cleavage [25]. Consistent with these observations, when assayed under similar conditions, purified PHM was several fold less active than purified PAL [20].

\section{Relationship with serum metals}

Since PHM and PAL utilize $\mathrm{Cu}$ and $\mathrm{Zn}$ for their enzymatic activities and are co-released from secretory vesicles, we investigated the relationship between PHM or PAL activity and serum $\mathrm{Cu}$ and $\mathrm{Zn}$ levels. Pearson correlation analyses revealed a significant linear relationship between serum $\mathrm{Cu}$ and PAL activity, but not PHM activity $(p<0.05)$ (Figure 2A,B). Serum $\mathrm{Cu}$ and ceruloplasmin activity correlated strongly and directly, as expected (Figure 2C). Serum Zn did not correlate with PHM, PAL or ceruloplasmin activity (data not shown).

In our previous study of this same cohort [19], we found significant relationships between the serum $\mathrm{Cu} / \mathrm{Zn}$ ratio 
Table 1 Serum amidating activity: descriptive statistics

\begin{tabular}{|c|c|c|c|c|c|c|}
\hline Enzyme & Mean & $\begin{array}{c}\text { Standard } \\
\text { error }\end{array}$ & $\begin{array}{l}\text { Standard } \\
\text { deviation }\end{array}$ & Variance & Skewedness & Kurtosis \\
\hline PHM & 5.51 & 0.10 & 1.11 & 1.24 & $0.24 \pm 0.22$ & $0.71 \pm 0.43$ \\
\hline PAL & 19.1 & 0.4 & 4.5 & 20.3 & $-0.08 \pm 0.22$ & $0.14 \pm 0.43$ \\
\hline PHM/PAL & 0.30 & 0.01 & 0.78 & 0.01 & $0.92 \pm 0.22$ & $1.34 \pm 0.43$ \\
\hline
\end{tabular}

with various measures of health. Similar to the data for serum $\mathrm{Cu}$, the $\mathrm{Cu} / \mathrm{Zn}$ ratio correlated significantly with PAL activity $\left(R^{2}=0.023\right)$ and ceruloplasmin activity $\left(R^{2}=0.331\right)$, but not with PHM activity (data not shown). Consistent with these relationships, subjects in the highest quintile as sorted by serum PAL activity had significantly higher $\mathrm{Cu}$ levels compared to the middle quintile ( $p$ values $<0.05$, data not shown). Therefore, serum PAL activity may serve as an indicator of physical and overall health in our study population.

\section{SNP analysis}

The large variation we observed in serum PHM and PAL activities could arise from genetic variation in and/or regulation of the $P A M$ gene (Figure $3 \mathrm{~A}$ ) among our subjects. To address this question, we focused on eight common SNPs (minor allele frequencies 16-44\%) (Table 2). In addition to the 3' UTR rs5855 SNP, a set of seven haplotype TagSNPs (rs32680, rs249496, rs10038600, rs7733485, rs11952361, rs10515341, rs17296280) which had been identified from the 2008 HapMap CEU population dataset (Table 2; Figure 3) were examined. This set of eight markers provides correlation with the larger set of genotyped SNPs in the HapMap dataset in this region with an average $R^{2}=0.925$. The haploview pairwise marker linkage disequilibrium ( $\left.D^{\prime}\right)$ and correlations $\left(R^{2}\right)$ are illustrated in Figure 3B and $\mathrm{C}$, respectively. Two blocks of SNPs showing very limited recombination are evident: block 1 (rs32680, rs249496) and block 2 (rs10038600, rs7733485, rs11952361, rs10515341).

We compared contrasting minor allele carriers vs. major allele homozygotes (minor allele dominant effect model) or contrasting minor allele homozygotes vs. major allele carriers (minor allele recessive model) for each SNP for serum amidating activity and $\mathrm{Cu} /$ ceruloplasmin levels (Table 3). Four SNPs were associated with differences in serum amidating activity. The upstream rs32680 minor allele homozygotes had significantly lower serum PHM and PAL activities $(\mathrm{t}=-2.38 ; p=0.019$ and $\mathrm{t}=-2.25 ; p=0.026$, respectively), without a significant difference in the PHM/

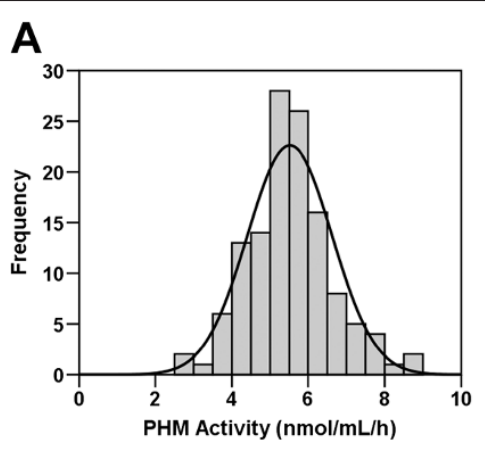

B
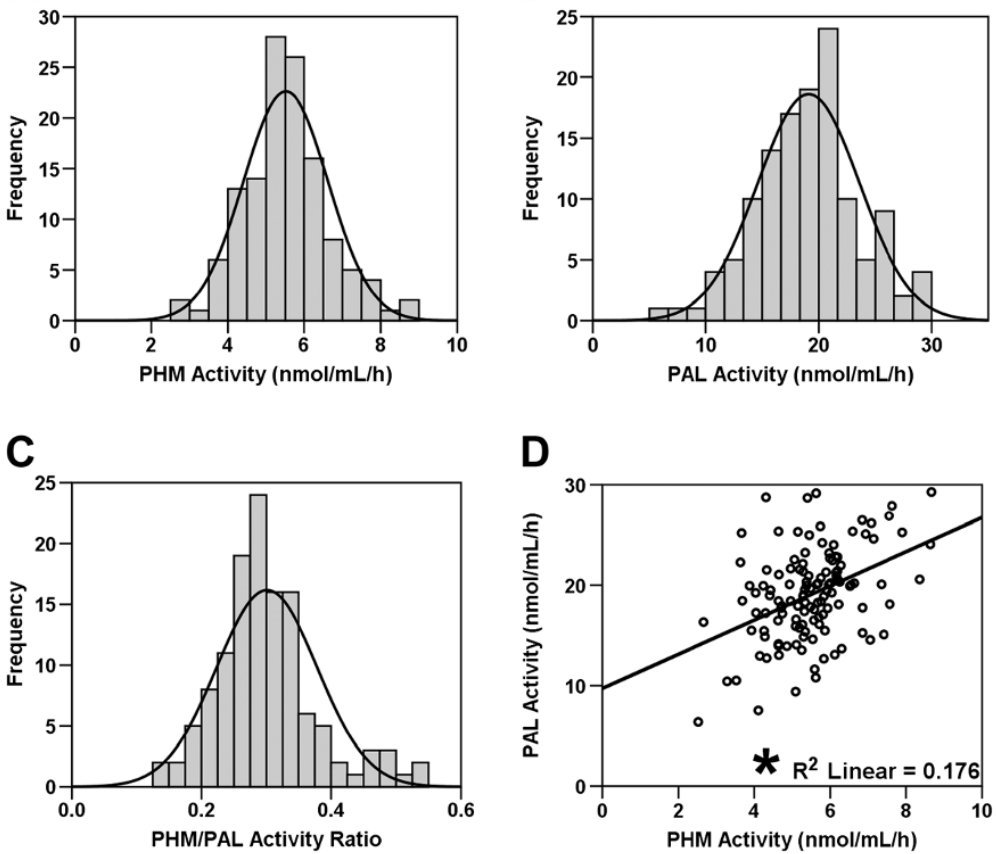

Figure 1 PHM and PAL Activities. Graphs depict frequency histograms for PHM (A) and PAL (B) activities, and the PHM/PAL activity ratio (C). (D) PHM and PAL activities for each subject are positively and linearly correlated. *depicts $p<0.05$ Pearson correlation. 

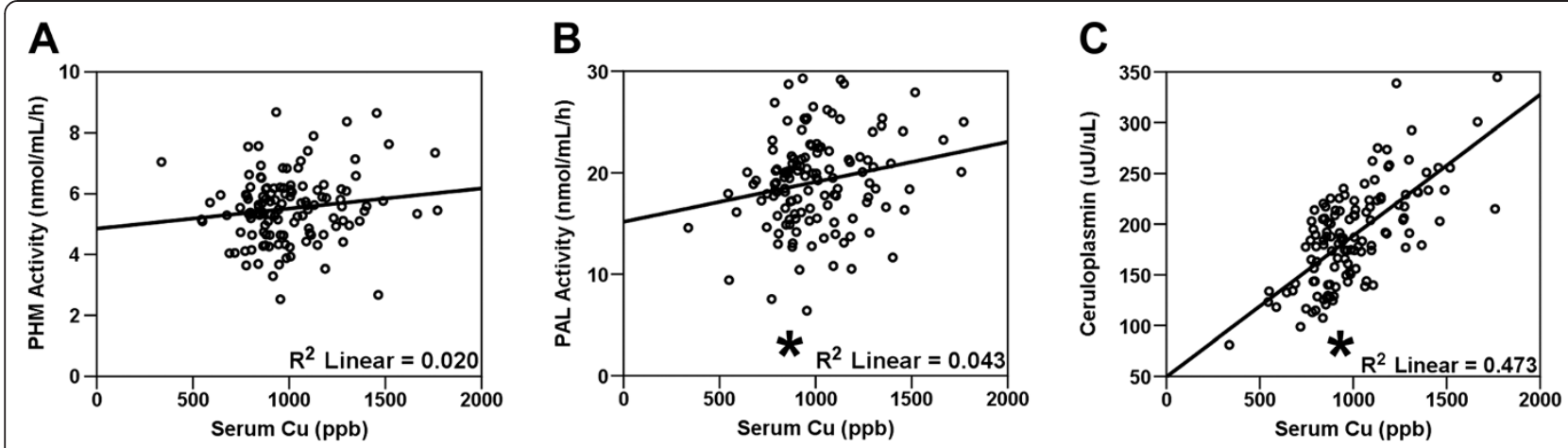

Figure 2 Serum amidating enzyme activities and metals. Scatter plots depict PHM (A), PAL (B) and ceruloplasmin (C) activities versus serum Cu. ${ }^{*}$ depicts $p<0.05$ Pearson correlation.

PAL ratio. The minor $\mathrm{T}$ allele at this locus may lower PAM enzyme activity through reduced expression of the PAM gene. The 5' UTR SNP rs249496 in the same block (block 1), showed no such differences in serum amidating activity. Lower PHM activities were present in the serum of subjects homozygous for the major $G$ allele at the rs10038600 locus in intron $3(\mathrm{t}=-2.07 ; p=0.041)$, homozygote subjects for the minor $G$ allele at rs11952361 in intron $10(\mathrm{t}=-2.01 ; p=0.047)$, and the minor but ancestral A allele at rs10515341 in intron $13(\mathrm{t}=-2.89 ; p=0.005)$, all of which are in the same haplotype block (block 2). Although PAL activity followed a similar trend, none

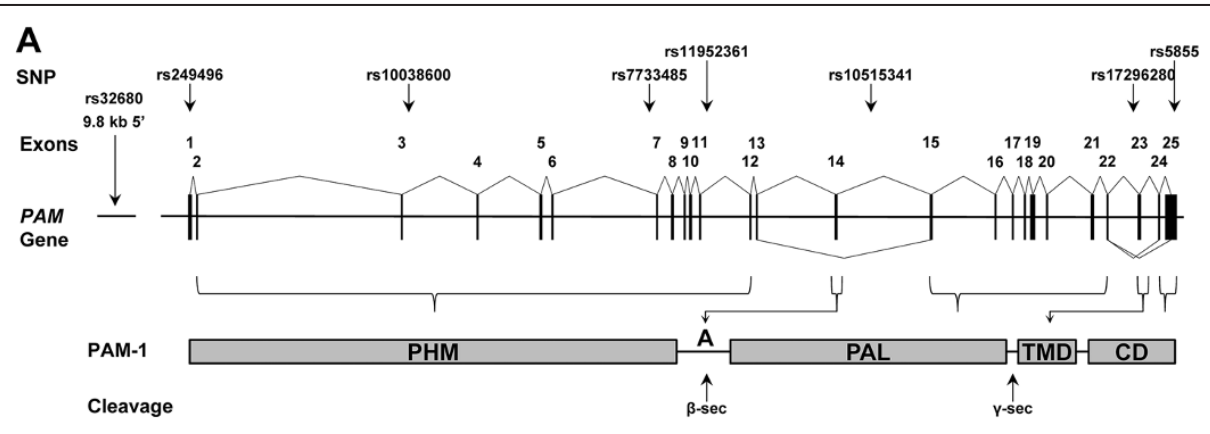

B

C
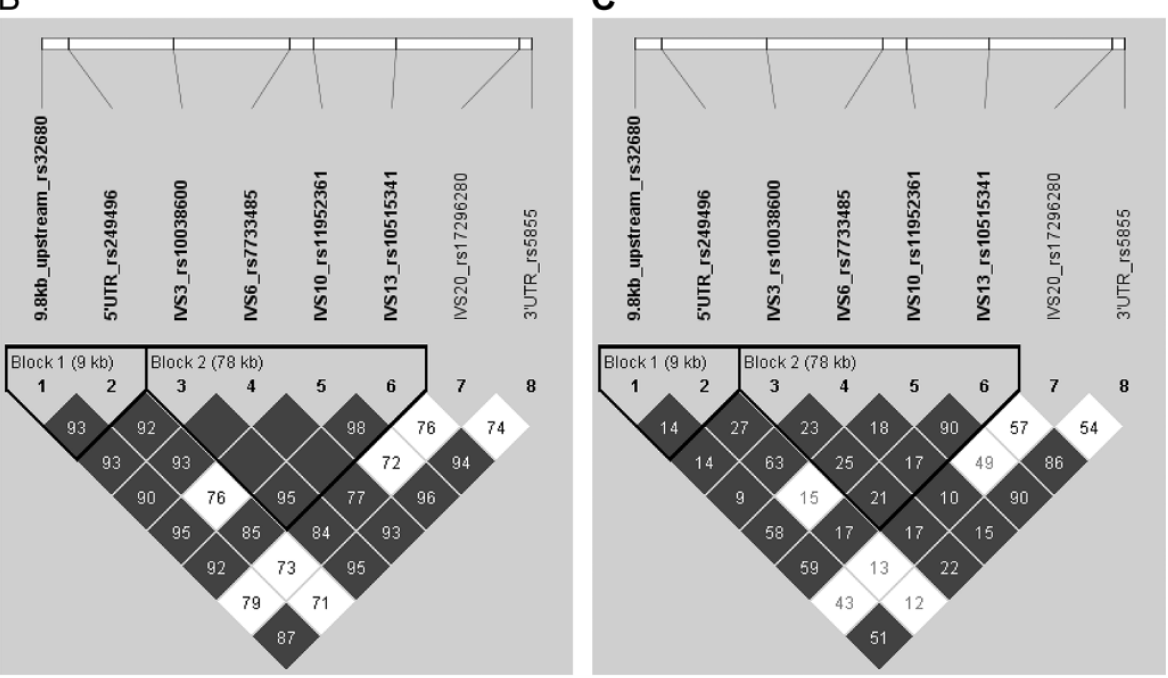

Figure 3 SNPs in PAM. (A) Schematic of the PAM gene with loci of SNPs examined in this study. (B,C) Haploview LD plot for eight PAM gene SNPs with haplotype blocks identified using the four-gamete rule [26]. Darkened blocks indicate SNP pairs without evidence of extensive recombination (i.e. 4-gamete having a frequency $<0.01$ ). (B) LD plot showing $D^{\prime}-$ Values shown represent $100 \times\left|D^{\prime}\right|$, empty boxes represent value of 100 (i.e. $\left|D^{\prime}\right|=1$ ). (C) Haploview LD plot showing $R^{2}$ correlation values. 
Table 2 PAM SNPs studied

\begin{tabular}{lccccc}
\hline SNP & Ch5 position & Alleles & GERP & Location & MAF \\
\hline rs32680 & 102191715 & G:T & -1.99 & $9.8 \mathrm{~kb}-5^{\prime}$ & 0.159 \\
rs249496 & 102201590 & G:C & 3.31 & $5^{\prime}$ UTR & 0.441 \\
rs10038600 & 102238502 & G:T & -0.469 & IVS3 & 0.225 \\
rs7733485 & 102279540 & A:G & 3.42 & IVS6 & 0.271 \\
rs11952361 & 102287920 & A:G & -0.47 & IVS10 & 0.360 \\
rs10515341 & 102317117 & G:A & -7.79 & IVS13 & 0.274 \\
rs17296280 & 102360747 & A:C & -0.328 & IVS20 & 0.270 \\
rs5855 & 102365186 & A:G & 5.93 & 3'UTR & 0.326 \\
\hline
\end{tabular}

of the associations was significant. PHM/PAL ratios were not different among these genotypes for any of these SNP loci, suggesting that any potential regulatory effects of these SNPs do not selectively influence expression of either enzyme.

With respect to serum $\mathrm{Cu}$ and ceruloplasmin, significantly lower serum $\mathrm{Cu}$ was found in subjects homozygous for the major G-allele at the rs249496 locus in the $5^{\prime}$ UTR ( $\left.\mathrm{t}=-2.43 ; p=0.016\right)$ and for subjects homozygous for the minor T-allele at the rs10038600 locus in intron 3 (Table 3). Consistent with the tight association between $\mathrm{Cu}$ and ceruloplasmin (Figure $2 \mathrm{C}$ ), serum ceruloplasmin followed the same associations for these SNP genotypes. Interestingly, the $\mathrm{Cu} /$ ceruloplasmin ratio, a measure of relative un-bound serum $\mathrm{Cu}$, was elevated in homozygous subjects for the minor T-allele at rs10038600 $(\mathrm{t}=2.29 ; p=0.024)$.

\section{Discussion}

In the current study, we characterized the distribution of the two activities essential for serum amidating activity, identified relationships between both enzyme activities and their metal cofactors, and found several associations between TagSNP polymorphisms and serum amidating activity and serum $\mathrm{Cu}$ in a population of elderly men. This is the first study to examine potential determinants and clinical relevance of the two components of serum amidating activity in human subjects; examination of similar parameters in additional study populations is needed to determine which conclusions can be generalized.

\section{Serum enzymes and their metal cofactors}

Since PHM and PAL are derived from the same gene product in mammals, with PHM requiring $\mathrm{Cu}$ and PAL using $\mathrm{Zn}$, assessment of their serum activities and their associations provides insight into the nature and determinants of serum amidating activity. The full-length, integral membrane PAM-1 protein, containing both PHM and PAL domains, is the predominant isoform expressed in mammalian tissues [27]. PHM and PAL are liberated from the transmembrane domain of PAM-1 and made soluble within the regulated secretory pathway by prohormone convertases 1 and/or 2; on the plasma membrane and in the endocytic pathway, other endoproteases, including $\alpha$-secretase and $\gamma$-secretase, can separate PAL from the transmembrane domain and cleave within the PAM transmembrane domain [28]. It is important to note that we added optimal divalent metals to each enzyme assay, so the measured serum activity reflects PHM and PAL protein content without regard to individuals with low serum metal levels. That the PHM and PAL activities were normally distributed, varied among our subjects, and strongly correlated with one another reflects the fact that both are usually produced together as a bifunctional enzyme.

Variation in human serum amidating activity was greater than 20\% (Figure 1), exceeding the less than 10\% variation observed in inbred mice [12,13]. Mice heterozygous for a knock-out copy of the gene encoding PAM have half the normal levels of serum amidating activity and PAM protein in all tissues studied. These mice display profound physiological and behavioral deficits, reinforcing the importance of having the full complement of PAM [12-14,16]. The degree of variation observed in humans means that our small sample set included individuals with only half the mean value of PHM or PAL, a potentially significant decrease (Figure 1). Over 75 rare $(<1 \%)$ mutations in the PAM gene that could inactivate PHM or PAL or truncate the PAM protein have been annotated in the human genome database (http://www. ncbi.nlm.nih.gov/SNP/snp_ref.cgi?locusId=5066). However, no human disease state has yet to be attributed directly to PAM dysfunction or insufficiency. Sequencing of the PAM gene should be considered in patients with deficits that resemble the phenotype of Pam heterozygous mice, including temperature dysregulation, metabolic syndrome, anxiety and memory impairments.

Levels of PAL, but not PHM, correlated with serum $\mathrm{Cu}$, and neither activity correlated with serum $\mathrm{Zn}$. Since the major tissue sources of serum PHM and PAL remain unknown, it is difficult to interpret this unexpected result. PHM and PAL bind their respective metal cofactors with relatively low affinity compared to many other metalloenzymes $[20,29,30]$. Some Cu-dependent enzymes are more stable with $\mathrm{Cu}$ bound than when not metallated [31]; this does not appear to be the case for PAM, since neither PHM nor PAL activity correlated with its respective metal co-factor. When cultured pituitary tumor cells expressing membrane PAM were made copper deficient, secretion of PHM increased and endocytic degradation of PAM decreased [32]. Similarly, when C57BL/6 mice were fed a copper deficient diet, serum PHM activity rose [12-14,16]. Although our data suggest that PAM participates in the cell-type specific 
Table 3 PAM SNP genotype relationships with serum PHM and PAL activity and metals

\begin{tabular}{|c|c|c|c|c|c|c|c|c|c|c|c|c|}
\hline SNP & & rs32680 & & & rs249496 & & & rs10038600 & & & rs7722485 & \\
\hline Geno-type & CC (73) & CT (39) & $\mathrm{TT}(8)$ & CC (18) & CG (48) & GG (54) & GG (50) & GT (52) & $\mathrm{TT}(18)$ & AA (64) & AG (43) & GG (13) \\
\hline PHM & $5.57 \pm 0.97 \S$ & $5.69 \pm 1.25 \S$ & $4.68 \pm 1.13 \S † \neq$ & $5.54 \pm 1.02$ & $5.56 \pm 1.03$ & $5.54 \pm 1.19$ & $5.31 \pm 1.05 † \neq$ & $5.78 \pm 1.14 \S$ & $5.56 \pm 1.00$ & $5.58 \pm 1.24$ & $5.58 \pm 0.91$ & $5.32 \pm 0.96$ \\
\hline PAL & $19.3 \pm 4.2 \S$ & $19.7 \pm 4.6 \S$ & $15.9 \pm 4.7 \S \dagger \neq$ & $20.2 \pm 5.0$ & $19.6 \pm 3.9$ & $18.5 \pm 4.6$ & $19.2 \pm 4.5$ & $19.4 \pm 4.6$ & $18.6 \pm 3.7$ & $18.7 \pm 4.6$ & $19.8 \pm 3.8$ & $19.6 \pm 5.3$ \\
\hline PHM/PAL & $0.30 \pm 0.08$ & $0.30 \pm 0.07$ & $0.32 \pm 0.11$ & $0.29 \pm 0.08$ & $0.29 \pm 0.07$ & $0.31 \pm 0.08$ & $0.29 \pm 0.08$ & $0.31 \pm 0.08$ & $0.31 \pm 0.09$ & $0.31 \pm 0.09$ & $0.29 \pm 0.06$ & $0.29 \pm 0.10$ \\
\hline $\mathrm{Cp}$ & $186 \pm 44$ & $194 \pm 49$ & $192 \pm 49$ & $207 \pm 47 \S$ & $195 \pm 43$ & $178 \pm 46 \S \ddagger$ & $196 \pm 51 \S$ & $192 \pm 41 \S$ & $160 \pm 32 \S † \ddagger$ & $182 \pm 45$ & $197 \pm 49$ & $198 \pm 34$ \\
\hline $\mathrm{Cu}$ & $996 \pm 209$ & $1013 \pm 256$ & $975 \pm 302$ & $1076 \pm 218 \S$ & $1027 \pm 236$ & $951 \pm 221 \S \ddagger$ & $1045 \pm 254 \S$ & $984 \pm 223$ & $921 \pm 144 \S \ddagger$ & $981 \pm 226$ & $1020 \pm 248$ & $1030 \pm 188$ \\
\hline $\mathrm{Zn}$ & $846 \pm 284$ & $911 \pm 263$ & $828 \pm 199$ & $879 \pm 273$ & $853 \pm 283$ & $872 \pm 268$ & $903 \pm 305$ & $834 \pm 237$ & $853 \pm 274$ & $871 \pm 250$ & $866 \pm 321$ & $839 \pm 213$ \\
\hline $\mathrm{Cu} / \mathrm{Zn}$ & $1.26 \pm 0.36$ & $1.17 \pm 0.37$ & $1.18 \pm 0.23$ & $1.31 \pm 0.39$ & $1.26 \pm 0.29$ & $1.17 \pm 0.40$ & $1.23 \pm 0.35$ & $1.24 \pm 0.37$ & $1.16 \pm 0.37$ & $1.19 \pm 0.38$ & $1.26 \pm 0.36$ & $1.27 \pm 0.24$ \\
\hline $\mathrm{Cu} / \mathrm{Cp}$ & $5.51 \pm 1.17$ & $5.31 \pm 0.89$ & $5.08 \pm 1.00$ & $5.33 \pm 1.05$ & $5.38 \pm 1.05$ & $5.48 \pm 1.12$ & $5.43 \pm 0.97$ & $5.22 \pm 1.05 \S$ & $5.94 \pm 1.30 \dagger$ & $5.51 \pm 1.05$ & $5.32 \pm 1.19$ & $5.25 \pm 0.75$ \\
\hline
\end{tabular}


Table 3 PAM SNP genotype relationships with serum PHM and PAL activity and metals (Continued)

\begin{tabular}{|c|c|c|c|c|c|c|c|c|c|c|c|c|}
\hline \multirow{2}{*}{$\frac{\text { SNP }}{\text { Geno-type }}$} & \multicolumn{3}{|c|}{ rs11952361 } & \multicolumn{3}{|c|}{ rs10515341 } & \multicolumn{3}{|c|}{ rs17296280 } & \multicolumn{3}{|c|}{ rs5855 } \\
\hline & AA (60) & AG (45) & GG (15) & AA (13) & AG (46) & GG (61) & $A A(61)$ & AC (47) & CC (12) & AA (60) & AG (47) & GG (13) \\
\hline PHM & $5.64 \pm 1.01$ & $5.60 \pm 1.09$ & $5.03 \pm 1.36 \neq$ & $4.74 \pm 0.99 \S † \ddagger$ & $5.69 \pm 1.16 \S$ & $5.62 \pm 1.00 \S$ & $5.55 \pm 0.97$ & $5.66 \pm 1.21$ & $5.11 \pm 1.20$ & $5.65 \pm 1.03$ & $5.54 \pm 1.06$ & $5.10 \pm 1.43$ \\
\hline PAL & $19.3 \pm 4.1$ & $19.5 \pm 5.0$ & $18.0 \pm 4.0$ & $17.1 \pm 3.7$ & $19.5 \pm 5.0$ & $19.4 \pm 4.1$ & $19.3 \pm 4.2$ & $19.4 \pm 4.7$ & $17.8 \pm 4.7$ & $19.4 \pm 4.2$ & $19.4 \pm 4.8$ & $17.7 \pm 4.1$ \\
\hline PHM/PAL & $0.31 \pm 0.08$ & $0.30 \pm 0.07$ & $0.29 \pm 0.09$ & $0.29 \pm 0.09$ & $0.30 \pm 0.07$ & $0.30 \pm 0.08$ & $0.30 \pm 0.08$ & $0.30 \pm 0.07$ & $0.30 \pm 0.09$ & $0.30 \pm 0.08$ & $0.30 \pm 0.07$ & $0.30 \pm 0.09$ \\
\hline$C p$ & $183 \pm 38 \dagger$ & $202 \pm 51 \S$ & $175 \pm 52$ & $168 \pm 50 \dagger$ & $198 \pm 48 \S$ & $186 \pm 42$ & $190 \pm 44$ & $191 \pm 49$ & $173 \pm 41$ & $186 \pm 38$ & $195 \pm 53$ & $180 \pm 51$ \\
\hline $\mathrm{Cu}$ & $989 \pm 212$ & $1020 \pm 225$ & $986 \pm 314$ & $946 \pm 308$ & $1023 \pm 232$ & $994 \pm 212$ & $989 \pm 195$ & $1020 \pm 267$ & $980 \pm 256$ & $998 \pm 210$ & $1002 \pm 228$ & $1003 \pm 330$ \\
\hline $\mathrm{Zn}$ & $840 \pm 228$ & $894 \pm 339$ & $884 \pm 216$ & $885 \pm 233$ & $899 \pm 332$ & $837 \pm 229$ & $822 \pm 225$ & $909 \pm 331$ & $921 \pm 217$ & $842 \pm 227$ & $885 \pm 336$ & $906 \pm 213$ \\
\hline $\mathrm{Cu} / \mathrm{Zn}$ & $1.22 \pm 0.30$ & $1.25 \pm 0.44$ & $1.14 \pm 0.32$ & $1.09 \pm 0.29$ & $1.24 \pm 0.42$ & $1.24 \pm 0.32$ & $1.26 \pm 0.34$ & $1.20 \pm 0.39$ & $1.09 \pm 0.29$ & $1.23 \pm 0.30$ & $1.24 \pm 0.43$ & $1.13 \pm 0.34$ \\
\hline $\mathrm{Cu} / \mathrm{Cp}$ & $5.54 \pm 1.17$ & 5.160 .89 & 5.701 .09 & $5.70 \pm 1.17$ & $5.24 \pm 0.88$ & $5.50 \pm 1.18$ & $5.36 \pm 1.14$ & $5.43 \pm 1.00$ & $5.71 \pm 1.02$ & $5.50 \pm 1.17$ & $5.27 \pm 0.95$ & $5.57 \pm 1.07$ \\
\hline
\end{tabular}

The number of subjects (120 total) of each genotype is shown in parenthesis.

Haplotype blocks are indicted by bold borders.

\pm SD.

Versus 1 OR $3 p<0.05(t \text {-test })^{s}$

Versus $2 p<0.05$ (t-test)

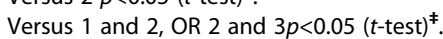


control of copper homeostasis, we do not yet have a satisfying understanding of the entire system.

\section{Genetic regulation of serum amidating activity}

Several hundred SNPs have been annotated in the PAM gene (http://www.ncbi.nlm.nih.gov/SNP/snp_ref.cgi?locusId=5066), many of which code for potentially impactful changes in amino acid sequence or regulation of PAM expression/splicing. The SNPs we examined are common and have no impact on PAM primary structure, yet they showed significant correlations with serum amidating activity and correlate with associated metal levels.

We observed significant minor allele associations with reduced serum PHM activity in block 1 (rs32680) and block 2 (rs11952361 and rs10515341), consistent with a minor allele recessive model for these markers. Significantly reduced PAL activity was found for minor allele homozygotes only at rs32680, with a trend towards reduction for minor allele homozygotes at the two block 2 SNPs (rs11952361 and rs10515341). The concordance of effects for PHM and PAL at these three markers likely reflects their production from the same gene product. Minor splice variants encoding only PHM have been identified [33] and one or more of these SNPs may be involved in regulating such splicing events.

These SNPs could affect serum amidating activity through a variety of mechanisms. Up- and down-stream UTR SNPs can alter mRNA stability through microRNA binding. Intron SNPs can affect alternative splicing, which determines whether PAM is an integral membrane or soluble protein and whether an endoproteolytic cleavage site separates PHM from PAL (Figure 3A).

SNPs in both blocks 1 (rs249496) and 2 (rs10038600) were associated with differences in serum $\mathrm{Cu}$. Similar relationships were found for ceruloplasmin, as might be expected given the strong correlation between $\mathrm{Cu}$ and ceruloplasmin. At rs10038600, however, homozygosity for the minor T-allele was associated with lower serum $\mathrm{Cu}$ and even lower ceruloplasmin as the $\mathrm{Cu} /$ ceruloplasmin ratio was elevated in these individuals. Interestingly, homozygosity for the major G-allele at the same locus was associated with lower serum PHM activity, possibly reflecting a dual influence or potential regulatory influence of PHM and $\mathrm{Cu}$ homeostasis (see above). This SNP is located at the $5^{\prime}$ end of intron 3 , a prime position to influence alternative splicing of exon 3; this could in turn affect $\mathrm{Cu}$ binding of PHM. In vitro experiments are necessary to test this hypothesis.

\section{Conclusions}

The tissue sources of serum amidating activity have not yet been identified. While studies of PAM processing and secretion in a pituitary tumor cell line identified a regulatory role for $\mathrm{Cu}$ [32], it is not yet possible to extend these in vitro studies to the in vivo situation. The determinants of serum amidating activity are clearly complex and need to be studied as part of the multi-organ $\mathrm{Cu}$ homeostasis network now beginning to be elucidated [34]. The data presented here support the idea that manipulation of the PAM gene in laboratory models may be a useful tool to study this complex relationship. Additionally, serum amidating activity may serve as a biomarker for certain disease states, including measures of frailty and physical health in the elderly and in Cu deficiency.

\section{Competing interests}

The authors declare that they have no competing interests.

\section{Authors' contributions}

All authors worked together to conceive of the study. AK and AMK collected the original data and serum samples. JC carried out the genetic studies and drafted the corresponding portions of the manuscript. MR performed all serum metal measurements. EDG performed PAM enzyme assays, did the statistical analyses and drafted the manuscript. EDG, BAE, REM and JC participated in study design and coordination to finalize the manuscript. All authors read and approved the final manuscript.

\section{Acknowledgements}

This work was supported by a University of Connecticut Incentive Grant and by a grant from the National Institutes of Health (DK032949). We thank Darlene D'Amato for assistance with sample handling and enzyme assays.

\section{Author details}

'Department of Neuroscience, University of Connecticut Health Center, 06030 Farmington, CT, USA. ${ }^{2}$ Center on Aging, University of Connecticut Health Center, 06030 Farmington, CT, USA. ${ }^{3}$ Department of Biochemistry and Molecular Biology, Oregon Health \& Science University, 97239 Portland, OR, USA. ${ }^{4}$ Department of Psychiatry, University of Connecticut Health Center, 06030 Farmington, CT, USA.

Received: 21 April 2014 Accepted: 7 July 2014

Published: 15 July 2014

\section{References}

1. Eipper BA, Mains RE: Peptide alpha-amidation. Annu Rev Physio/ 1988, 50:333-344.

2. Eipper BA, Stoffers DA, Mains RE: The biosynthesis of neuropeptides: peptide alpha-amidation. Annu Rev Neurosci 1992, 15:57-85.

3. Eipper BA, Glembotski CC, Mains RE: Bovine intermediate pituitary alpha-amidation enzyme: preliminary characterization. Peptides 1983, 4:921-928.

4. Czyzyk TA, Ning Y, Hsu MS, Peng B, Mains RE, Eipper BA, Pintar JE: Deletion of peptide amidation enzymatic activity leads to edema and embryonic lethality in the mouse. Dev Biol 2005, 287:301-313.

5. Prigge ST, Kolhekar AS, Eipper BA, Mains RE, Amzel LM: Amidation of bioactive peptides: the structure of peptidylglycine alpha-hydroxylating monooxygenase. Science 1997, 278:1300-1305.

6. Prigge ST, Mains RE, Eipper BA, Amzel LM: New insights into copper monooxygenases and peptide amidation: structure, mechanism and function. Cell Mol Life Sci 2000, 57:1236-1259.

7. Eipper BA, Green CBR, Campbell TA, Stoffers DA, Keutmann HT, Mains RE, Ouafik L: Alternative splicing and endoproteolytic processing generate tissue-specific forms of PAM. J Biol Chem 1992, 267:4008-4015.

8. Milgram SL, Johnson RC, Mains RE: Expression of individual forms of peptidylglycine alpha-amidating monooxygenase in AtT-20 cells: endoproteolytic processing and routing to secretory granules. J Cell Biol 1992, 117:717-728.

9. Mains RE, Eipper BA: Peptides. In Basic Neurochemistry, Molecular, Cellular and Medical Aspects. 7th edition. Edited by Siegel GR, Albers W, Brady ST, Price DL. New York: Elsevier; 2006:317-332. 
10. El Meskini R, Boudouresque F, Ouafik L: Estrogen regulation of peptidylglycine alpha-amidating monooxygenase messenger ribonucleic acid levels by a nuclear posttranscriptional event. Endocrinology 1997, 138:5256-5265.

11. Brenet F, Dussault N, Borch J, Ferracci G, Delfino C, Roepstorff P, Miquelis R, Ouafik L: Mammalian peptidylglycine alpha-amidating monooxygenase mRNA expression can be modulated by the La autoantigen. Mol Cell Biol 2005, 25:7505-7521.

12. Bousquet-Moore D, Prohaska JR, Nillni EA, Czyzyk T, Wetsel WC, Mains RE, Eipper BA: Interactions of peptide amidation and copper: novel biomarkers and mechanisms of neural dysfunction. Neurobiol Dis 2010, 37:130-140.

13. Bousquet-Moore D, Ma XM, Nillni EA, Czyzyk TA, Pintar JE, Eipper BA, Mains RE: Reversal of physiological deficits caused by diminished levels of peptidylglycine alpha-amidating monooxygenase by dietary copper. Endocrinology 2009, 150:1739-1747.

14. Gaier ED, Rodriguiz RM, Ma XM, Sivaramakrishnan S, Bousquet-Moore D, Wetsel WC, Eipper BA, Mains RE: Haploinsufficiency in peptidylglycine alpha-amidating monooxygenase leads to altered synaptic transmission in the amygdala and impaired emotional responses. J Neurosci 2010, 30:13656-13669.

15. Bousquet-Moore D, Mains RE, Eipper BA: Peptidylgycine alpha-amidating monooxygenase and copper: a gene-nutrient interaction critical to nervous system function. J Neurosci Res 2010, 88:2535-2545.

16. Gaier ED, Rodriguiz RM, Zhou J, Ralle M, Wetsel WC, Eipper BA, Mains RE: In vivo and in vitro analyses of amygdalar function reveal a role for copper. J Neurophysiol 2014, 111:1927-1939.

17. Gaier ED, Eipper BA, Mains RE: Pam heterozygous mice reveal essential role for $\mathrm{Cu}$ in amygdalar behavioral and synaptic function. Ann N Y Acad Sci 2014, 1314:15-23.

18. Kenny AM, Kleppinger A, Annis K, Rathier M, Browner B, Judge JO, McGee $D$ : Effects of transdermal testosterone on bone and muscle in older men with low bioavailable testosterone levels, low bone mass, and physical frailty. J Am Geriatr Soc 2010, 58:1134-1143.

19. Gaier ED, Kleppinger A, Ralle M, Mains RE, Kenny AM, Eipper BA: High serum $\mathrm{Cu}$ and $\mathrm{Cu} / \mathrm{Zn}$ ratios correlate with impairments in bone density, physical performance and overall health in a population of elderly men with frailty characteristics. Exp Gerontol 2012, 47:491-496.

20. Kolhekar AS, Bell J, Shiozaki EN, Jin L, Keutmann HT, Hand TA, Mains RE, Eipper BA: Essential features of the catalytic core of peptidyl-alpha-hydroxyglycine alpha-amidating lyase. Biochemistry 2002, 41:12384-12394.

21. Prohaska JR: Changes in $\mathrm{Cu}, \mathrm{Zn}$-superoxide dismutase, cytochrome c oxidase, glutathione peroxidase and glutathione transferase activities in copper-deficient mice and rats. J Nutr 1991, 121:355-363.

22. Prohaska JR, Broderius M: Plasma peptidylglycine alpha-amidating monooxygenase (PAM) and ceruloplasmin are affected by age and copper status in rats and mice. Comp Biochem Physiol B Biochem Mol Biol 2006, 143:360-366.

23. Barrett JC, Fry B, Maller J, Daly MJ: Haploview: analysis and visualization of LD and haplotype maps. Bioinformatics 2005, 21:263-265.

24. Baumgartner RN, Koehler KM, Gallagher D, Romero L, Heymsfield SB, Ross RR, Garry PJ, Lindeman RD: Epidemiology of sarcopenia among the elderly in New Mexico. Am J Epidemiol 1998, 147:755-763.

25. Husten EJ, Tausk FA, Keutmann HT, Eipper BA: Use of endoproteases to identify catalytic domains, linker regions and functional interactions in soluble PAM. J Biol Chem 1993, 268:9709-9717.

26. Wang N, Akey JM, Zhang K, Chakraborty R, Jin L: Distribution of recombination crossovers and the origin of haplotype blocks: the interplay of population history, recombination, and mutation. Am J Hum Genet 2002, 71:1227-1234.

27. Braas KM, Stoffers DA, Eipper BA, May V: Tissue specific expression of rat peptidylglycine a-amidating monooxygenase activity and mRNA. Mol Endocrinol 1989, 3:1387-1398.

28. Rajagopal C, Stone KL, Francone VP, Mains RE, Eipper BA: Tissue specific expression of rat peptidylglycine alpha-amidating monooxygenase activity and mRNA. J Biol Chem 2009, 284:25723-25734.

29. Bell J, Eipper BA, Mains RE: Amidation. In Encyclopedia of Endocrinology and Endocrine Diseases. Edited by Martini L. New York: Elsevier; 2004:188-191.

30. Madsen E, Gitlin JD: Copper and iron disorders of the brain. Annu Rev Neurosci 2007, 30:317-337.

31. Hellman NE, Kono S, Mancini GM, Hoogeboom AJ, De Jong GJ, Gitlin JD: Mechanisms of copper incorporation into human ceruloplasmin. J BiO Chem 2002, 277:46632-46638.
32. De M, Ciccotosto GD, Mains RE, Eipper BA: Trafficking of a secretory granule membrane protein is sensitive to copper. J Biol Chem 2007, 282:23362-23371.

33. Stoffers DA, Ouafik LH, Eipper BA: Characterization of novel mRNAs encoding enzymes involved in peptide alpha-amidation. $J$ Biol Chem 1991, 266:1701-1707.

34. Kim BE, Turski ML, Nose Y, Casad M, Rockman HA, Thiele DJ: Cardiac copper deficiency activates a systemic signaling mechanism that communicates with the copper acquisition and storage organs. Cell Metab 2010, 11:353-363.

doi:10.1186/1472-6823-14-58

Cite this article as: Gaier et al:: Genetic determinants of amidating enzyme activity and its relationship with metal cofactors in human serum. BMC Endocrine Disorders 2014 14:58.

\section{Submit your next manuscript to BioMed Central and take full advantage of:}

- Convenient online submission

- Thorough peer review

- No space constraints or color figure charges

- Immediate publication on acceptance

- Inclusion in PubMed, CAS, Scopus and Google Scholar

- Research which is freely available for redistribution

Submit your manuscript at www.biomedcentral.com/submit
C Biomed Central 